Archaeologia Historica Polona tom 25, 2017, ISSN 1425-3534

Centrum Archeologii Śródziemnomorskiej ～http://dx.doi.org/10.12775/AHP.2017.012 Uniwersytetu Warszawskiego

HENRYK PANER

\title{
Plakietka św. Brygidy z Gdańska i inne archeologiczne świadectwa kultu świętej Brygidy w znaleziskach europejskich
}

\section{The pilgrim sign of the Saint Brigit from Gdansk and other archaeological testimony of the Saint Brigit cult in the European discoveries}

Zarys treści. Pośród ponad 1200 średniowiecznych pamiątek pielgrzymich odnalezionych podczas badań wykopaliskowych w Gdańsku, pochodzących z ponad 40 europejskich sanktuariów, znaleziono również plakietkę z przedstawieniem świętej Brygidy. Kult tej świętej był powszechny na Pomorzu już w czasach jej współczesnych. Przyczyniło się do tego eksponowanie ciała św. Brygidy w kościele Mariackim oraz w kaplicy pokutnic w Gdańsku. Miało to miejsce w roku 1374, w trakcie transportowania jej zwłok z Rzymu do Vadsteny. Plakietka z Gdańska jest pierwszym znaleziskiem znaku pielgrzymiego z Vadsteny spoza obszaru Skandynawii.

Slowa kluczowe: średniowiecze, pielgrzymki, kult świętej Brygidy, Szwecja, Vadstenie, znaki pielgrzymie, pamiątki pielgrzymie, Gdańsk.

W trakcie badań wykopaliskowych prowadzonych w Gdańsku w 2012 roku przy ulicy Jaglanej $3 / 5^{1}$, w wykopie IV w warstwie 36, datowanej na okres późnośredniowieczny, natrafiono na doskonale zachowany średniowieczny znak pielgrzymi (nr inwentarza polowego 2912). Jego szerokość wynosi 29 mm, wysokość zaś $65 \mathrm{~mm}$. Przedstawia on świętą Brygidę w zakonnym habicie, frontalnie w pozycji siedzącej, która pisze księgę leżącą na pulpicie po jej prawej stronie i trzyma kałamarz w ręce lewej. Całość umieszczono w ramce zwieńczonej gotycką arkadą z flankującymi ją dwiema wieżami, pomiędzy którymi, nad wyraźnie zaznaczoną sferą niebios, znajdują się głowy ukoronowanej Marii i Chrystusa w krzyżowym nimbie. W dolnej części ramki znajduje się słabo zachowany napis

${ }^{1}$ Badaniami kierowała dr Anna Rembisz-Lubiejewska. 
S'BIRGITTA DE WATZSTEIS (ryc. 1; GKPP 1183) ${ }^{2}$. Znak ten pochodzi z klasztoru w Vadstenie w Szwecji, położonego w regionie Östergötland - macierzystej siedzibie zakonu brygidek, utworzonego przez świętą Brygidę w 1346 roku, przy wsparciu króla Szwecji Magnusa Erikssona IV, panującego w latach 1319-1364.

Lokalizacja innych europejskich znalezisk wskazuje, że do tego sanktuarium pielgrzymowali głównie mieszkańcy Skandynawii, jako że plakietki z Vadsteny (nieco ponad 60 egzemplarzy) - jak dotąd - odkryto jedynie na terenie Szwecji, Norwegii, Danii i Finlandii. Lars Andersson wyróżnił pięć grup tych przedmiotów, które były produkowane w Vadstenie i sprzedawane od początków XV do początków XVI wieku. Plakietka z Gdańska może być zaliczona do grupy V, datowanej na 2. połowę XV i początek XVI wieku (Andersson 1986, s. 101-108; 1989, s. 27-35). Od pozostałych znaków z Vadsteny zaliczonych do grup od I do IV, egzemplarz z Gdańska różni się zarówno samą kompozycją przedstawienia, jak i kształtem ramki, a także krótszą inskrypcją zachowaną w brzmieniu $S$ ' BIRGITTA DE WATZSTEIS.

W Szwecji dwie plakietki, identyczne jak te z Gdańska, znaleziono w Uppsali (Andersson 1986, s. 107, nr V: 1; 1989, s. 32-33, nr V-1), pięć w klasztorze Alvastra, gdzie natrafiono również na muszle z Santiago de Compostela (Köster 1983, s. 131, nr M27; Andersson 1989, s. 110, nr 68, 69, 70) oraz plakietki z Akwizgranu (Rydbeck 1957, s. 296, ryc. 1-2; Rhein und Maas 1972, s. 150, nr 6; Spencer 1990, s. 26; Rong 2000, s. 38-39, nr 13, ryc. 13; Poettgen 2009, s. 92-93, kat. nr 30) i Wilsnack datowane na 1. połowę XV wieku (Andersson 1989, s. 58, nr 2).

Na północy Szwecji w miejscowości Piteå, znaleziono fragmentarycznie zachowaną plakietkę reprezentującą kolejny rodzaj znaków produkowanych w Vadstenie i datowanych na 1. połowę XV wieku. W wyżej wspomnianej klasyfikacji L. Andressona plasuje się ona w grupie I. Postać świętej jest tu ukazana z półprofilu, zwrócona w lewo lub w prawo; pisze ona książkę umieszczoną na pulpicie. Powyżej znajduje się wskazująca na świętą Brygidę ręka Boga. Scenę umieszczono w prostokątnej ramce z trójkątnym zakończeniem zwieńczonym krzyżem i flankowanym przez dwie wieże. Dookoła ramki znajduje się napis, najczęściej w brzmieniu SANTTA (of sancta) BERIDA IN VATST(ena) M(onas) T(erio) AVE MARIA. Takie same znaki znaleziono też w innych zakątkach Szwecji, między innymi trzy w Gudmundrå (Kramfors), dwa w Grödinge (Andersson 1989, s. 31, nr III: R6), po jednym w Vadstenie, Annerstad, Vittaryd (Andersson 1989, s. 29-31, nr I: 1, I: 6, II: R1, II: 3, II: 4, III: 2, IV: 2), Söderby-Karl (Ugglas af. 1943, s. 84; Andersson 1985, s. 50), Sztokholmie (Andersson 1986, s. 104, nr II: 3; 1989, s. 29, nr I: 3), Lund (Andersson 1986, s. 105, nr II: 2; 1989, s. 30, nr I: 2), Nyköping (Andersson 1989, s. 31, nr III: 1), Torsås (Andersson 1986, s. 106, nr III: R5), Katslösa nieopodal Ystad (Andersson 1986, s. 105, nr III: R3; 1989, s. 31,

${ }^{2}$ GKPP - Gdańska Kolekcja Pamiątek Pielgrzymich. Badaniami kierowała dr Anna Rembisz-Lubiejewska. 


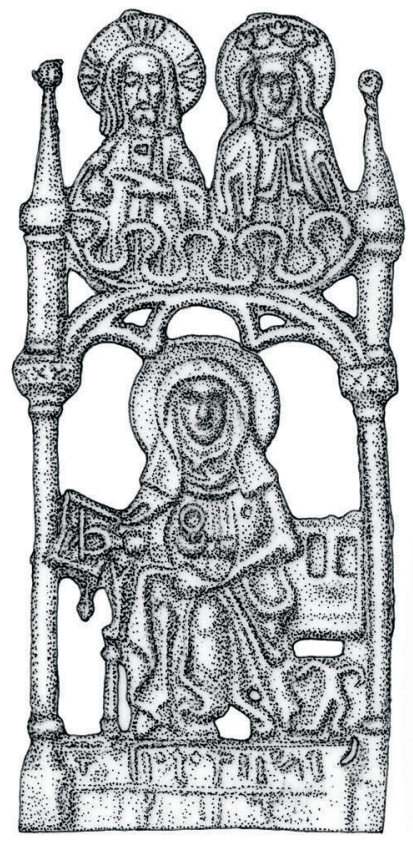

i................

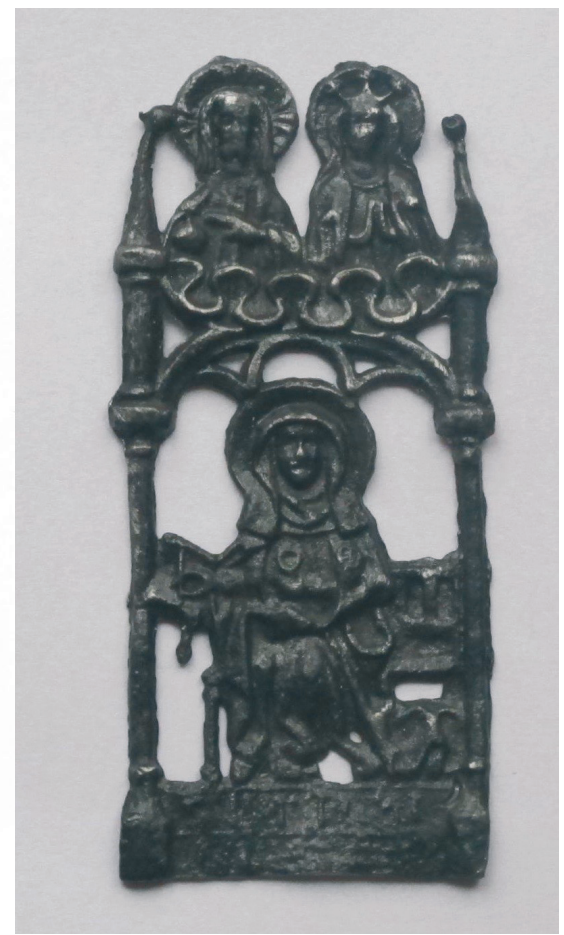

Ryc. 1. Plakietka z Vadsteny (GKPP 1183) z wizerunkiem świętej Brygidy (rys. E. Nowicka, fot. H. Paner)

Fig. 1. The Vadstena badge (GKPP 1183) with the representation of St Bridget (drawing by E. Nowicka, photo by H. Paner)

nr III: R3) oraz jedną, dokładnie datowaną na lata 1450-1453 w Tjureda (Andersson 1989, s. 31, nr III: R4). Cztery tego rodzaju przedmioty znane są również z terenu Gotlandii (Andersson 1989, s. 30, nr II: 2, s. 31, nr III: R1, s. 32, nr IV: R1).

W Norwegii prawie wszystkie znaleziska plakietek z wyobrażeniem świętej Brygidy pochodzą z południowej części kraju. Wśród nich tylko jeden znak z napisem S' BIRGITTA DE WATZSTEIS, znaleziony w miejscowości Sauda, jest identyczny jak znalezisko z Gdańska i datowany na lata 1475-1524 (Andersson 1989, s. 34, nr V: RV), drugi zaś jest znany w postaci odlewu na dzwonie z miejscowości Gjerde (Hauglid 1942, s. 71; Andersson 1989, s. 34, nr V: RIV). Pozostałe oryginalne plakietki można zaliczyć do typu z dłuższym napisem, tj. SANTTA (of sancta) BERIDA IN VATST(ena) M(onas)T(erio) AVE MARIA i znane są z Oslo, Uvdal, Nesland oraz Berg. Cztery takie znaki zachowały się w postaci odlewów na dzwonach z miejscowości Gjerde, datowanych na 2. połowę XV wieku (Wallem 1930, s. 33; Köster 1979, s. 402-403, 421, nr 40; Andersson 1986, s. 106, nr IV: R). 
Spośród kilkunastu, znanych z Danii plakietek z wizerunkiem świętej Brygidy, tylko siedem to oryginalne znaki pielgrzymie, pozostałe zaś są odlewami na dzwonach kościelnych. Podobne do plakietek z Vadsteny są egzemplarze produkowane w klasztorze świętej Brygidy w Maribo, położonym w regionie Zealand w południowej Danii, ukończonym w roku 1437. Stosunkowo wczesny odlew tego znaku został umieszczony na dzwonie kościelnym datowanym na rok 1437 (Andersson 1986, s. 108-109; 1989, s. 46-48). Plakietki z tego ośrodka zostały - jak dotąd - znalezione wyłącznie na terenie Danii, przy czym tylko jedna w oryginalnej postaci; pochodzi ona z miejscowości Højby i datowana jest na lata 1425-1475 (Andersson 1989, s. 46, nr 1). Pozostałe znane sa jedynie z odlewów na dzwonach kościelnych znalezionych w Frøslev (1425-1475) (Uldall 1906, s. 203-204; Andersson 1986, s. 109, nr VI: R4; 1989, s. 47, nr R4), Varde (1425-1427) (Andersson 1989, s. 47, nr R5), Alsønderup (1425-1428) (Uldall 1906, s. 188; Andersson 1986, s. 109, nr VI: R1; 1989, s. 46, nr R1), Tågerup (1425-1475) (Uldall 1906, s. 87, ryc. 110) oraz Selsø (1425-1467) (Uldall 1906, s. 188; Andersson 1989, s. 47, nr R2). Odlewy tych plakietek przedstawiają postać świętej, piszącej księgę ułożoną na pulpicie, na którą skierowana jest ręka Boga.

Plakietki sprzedawane w sanktuarium świętej Brygidy w klasztorze Isleworth w Anglii, zwanym też Syon Abbey ${ }^{3}$, zbudowanym w 1415 roku z inicjatywy szlachcica nazwiskiem Henry Hitzhugh, przy wsparciu króla Henryka V, różnią się od plakietek z Vadsteny zarówno kształtem, jak i przedstawieniami. Oczywiście na wszystkich umieszczono postać świętej, jednakże z pewnymi odstępstwami w porównaniu do pamiątek z Vadsteny, jak choćby zwieńczenie plakietki przez Vera Icon (Mitchiner 1986, s. 178, kat. 572; Spencer 1990, s. 45-46), dodatkową ramką na lusterko umieszczoną pod przedstawieniem świętej przy pulpicie pisarskim (Mitchiner 1986, s. 178, kat. 573; Spencer 1990, s. 45-46, 81, ryc. 126), nieco inna inskrypcja, w tym przypadku w brzmieniu SCA BRIGT, czy też użycie ramek bogato zdobionych czołgankami (Spencer 1990, s. 45-46, 81, ryc. 125).

Klasztor Isleworth wabił pielgrzymów licznymi odpustami, niejednokrotnie tak samo atrakcyjnymi jak te, które nadawano w Rzymie, na przykład za nawiedzenie kościoła pod wezwaniem św. Piotra w Okowach (St. Peter ad Vincula), czy też w macierzystym klasztorze brygidek w Szwecji (Andersson 1986, s. 111-112; Spencer 1990, s. 45-46; 1998, s. 178-179). Znamy 17 plakietek pochodzących z Isleworth, przy czym tylko w przypadku dwóch znalezisk nie ustalono lokalizacji (Spencer 1998, s. 178, ryc. 198g; Bruna 2006, s. 273, 305); jedną odkryto w Salisbury (Spencer 1990, s. 45-46, nr 92, s. 81, ryc. 124), pozostałe zaś w Londynie (Catalogue 1954, s. 139, nr 685; Spencer 1990, s. 45-46, nr 92, s. 81, ryc. 124-126; 1998, s. 178-179, nr 198h; Andersson 1986, s. 112, nr VIII: 2, VIII: 3, VII: 4, VIII: 5, VIII: 6, VIII: 7; Mitchiner 1986, s. 178, kat. 572-574).

\footnotetext{
${ }^{3}$ Obecnie we wschodniej części Londynu.
} 
Jedyny znak znaleziony na terenie Finlandii w miejscowości Toijala z inskrypcją S' BIRGITTA DE WATZSTEIS, jest identyczny jak plakietka z Gdańska i datowany na lata 1475-1524 (Andersson 1989, s. 33, nr V: 8).

Poza Skandynawią znamy jedynie dwa odlewy plakietek z przedstawieniem świętej Brygidy, umieszczone na dzwonach kościelnych. Jeden pochodzi z terenu Niemiec, z miejscowości Altenahr (Gerhardt i in. 1938) i został odlany już w roku 1473 przez mistrza nazwiskiem Johann van Alfter. Prostokątna plakietka z trójkątnym zakończeniem, flankowanym dwiema wieżami, przedstawia świętą siedzącą przed pulpitem i piszącą książkę, nad którą znajduje się kapelusz pielgrzymi zawieszony na lasce pielgrzymiej (Andersson 1986, s. 109, nr VII: R2). Drugi znak widnieje na dzwonie odlanym w końcu XV wieku, zachowanym w kościele w Mielnie, powiat Łobez (Majewski 2013, s. 51-68, ryc. 10).

Święta Brygida, znana też jako Brygida Szwedzka, urodziła się w 1303 roku w miejscowości Finstad, położonej w prowincji Uppland we wschodniej Szwecji. Poprzez swego dziadka ze strony matki spokrewniona była z rodem królewskim, co dało jej szansę otrzymania starannego wykształcenia. Już jako dziecko doświadczała różnych wizji religijnych, które przedstawiały na ogół postać Matki Boskiej bądź też sceny związane z ukrzyżowaniem Chrystusa. Wydana wbrew swej woli za mąż za Ulfa Gundamarssona, zaraziła męża swoją religijnością i wspólnie z nim nawiedzała relikwie świętych w najsławniejszych sanktuariach ówczesnej Europy, między innymi świętego Olafa w Trondheim, Güstrow pomiędzy rokiem 1341 i 1342 oraz świętego Jakuba w Santiago de Compostela, skąd małżonkowie powrócili do Szwecji w roku 1342, po czym zamieszkali w klasztorze cysterskim w Alvastra. Warto zauważyć, że do czasu pojawienia się sanktuarium w Wilsnack to właśnie Güstrow było najbardziej popularnym w Niemczech ośrodkiem związanym z kultem Świętej Krwi, do którego, szczególnie w połowie XIV wieku, przybywały tłumnie pielgrzymki (Ansorge, Kühne 2009, s. 46-474). Nota bene w latach 1350-1384 aż siedem lubeckich testamentów zawierało wzmianki o pielgrzymkach do Güstrow w zastępstwie testatora. W roku 1346 król szwedzki Magnus Ericsson ofiarował po jednym złotym kielichu dla pięciu wyróżnionych przez siebie europejskich sanktuariów: Akwizgranu i Gottsbüren, Güstrow, Rocamadour oraz Santiago de Compostela (Ansorge 2013, s. 86). Kilka lat po śmierci męża zmarłego w roku 1344, Brygida udała się do Rzymu na obchody Roku Jubileuszowego 1350, gdzie również doznała

\footnotetext{
${ }^{4}$ Autorzy dokonali zestawienia źródeł dokumentujących pielgrzymki do tego ośrodka oraz identyfikacji plakietek z Güstrow. Por. też Ansorge 2013, s. 86, gdzie autor podaje informacje o uzyskaniu przez księcia Magnusa II von Mecklenburg w roku 1486 odpustu za odwiedzenie kaplicy Świętej Krwi w Güstrow. Miało to być pomocne w walce z ośrodkiem w Wilsnack o pielgrzymów i tym samym podratować malejące dochody.
} 
licznych objawień związanych z ówczesną sytuacja polityczną. Między innymi przepowiedziała spotkanie papieża i cesarza w Rzymie, choć wówczas wydawało się to nierealne, zważywszy, że już od roku 1309, tj. od czasów papieża Klemensa V, siedzibą papieży był Awinion, skąd dopiero w 1377 roku papież Grzegorz XI powrócił do Rzymu. W roku 1370 Brygida zatwierdziła u papieża Urbana V, ułożoną przez siebie regułę zakonu brygidek, po czym powołała ten zakon do życia . Rok później udała się na wymarzoną pielgrzymkę do Ziemi Świętej, w czasie której zmarł jej syn Karol, a ona poważnie nadszarpnęła swoje zdrowie, na skutek czego zmarła po powrocie do Rzymu 23 lipca 1373 roku. Ciało Brygidy przewieziono w roku 1374, via Gdańsk, do Vadsteny, gdzie 10 lat później powstał pierwszy klasztor brygidek. Ciało świętej w specjalnie wykonanym sarkofagu miało być eksponowane przez dwa tygodnie w kościele Mariackim oraz w tzw. kaplicy pokutnic pod wezwaniem św. Marii Magdaleny, znajdującej się obecnie wewnątrz kompleksu klasztoru św. Brygidy (Kamińska 1970, s. 36-93; Czaja 1998; Paner 2013, s. 41). Wspólnota pokutnic zrzeszała upadłe, biedne kobiety, dla których nie było wówczas miejsca w społeczności miejskiej. W tradycji ludowej zakorzeniony jest przekaz o cudownych właściwościach wody ze znajdującej się w pobliżu kaplicy studzienki, co miało być związane z objawieniem się tutaj Matki Boskiej około połowy XIV wieku (Keyser 1928, s. 250; Fankidejski 2011, s. 43). Kilkudniowy pobyt ciała świętej Brygidy w Gdańsku przyczynił się do niezwykłej popularności tego kultu na Pomorzu już w czasach jej współczesnych. Mieszkańcy tego regionu pielgrzymowali do Skandynawii, zaś z samego Gdańska znamy ślady kultu świętych skandynawskich - Olafa, Eryka i Brygidy. Jeszcze w 1. połowie XV wieku kilku mieszkańców Elbląga wybrało się w podróż do Vadsteny, gdzie spoczywały szczątki świętej Brygidy, a w roku 1454 mieszczanie i rycerze pruscy ślubowali przed obrazem świętej w Elblągu ufundowanie klasztoru jej reguły, prosząc jednocześnie o pomoc w uzyskaniu zwycięstwa nad Krzyżakami. W jednym z testamentów elbląskich, gdzie testatorem był sam burmistrz, znajdujemy zapis z prośbą o odbycie pielgrzymki za duszę testatora, właśnie do klasztoru brygidek w Vadstenie (Kubicki 2010, s. 179-1886; 2011, s. 7-26, tab. 6).

Nota bene to właśnie zakon krzyżacki był gorącym rzecznikiem promowania kultu świętej Brygidy, zarówno w Gdańsku, jak i na całym Pomorzu. Na prośbę wielkiego mistrza w 1392 roku przybyły do Gdańska pierwsze brygidki z klasztoru w Vadstenie, a w roku 1396 został tutaj erygowany klasztor Zakonu Najświętszego Zbawiciela, konsekrowany już w grudniu 1397 roku, do którego wstąpiła większość pokutnic, a także kościół pod wezwaniem św. Brygidy. Decyzją władz krzyżackich klasztor otrzymał wówczas nadanie w postaci wsi Pręgowo i Siedlce, niemniej ustanowiono wówczas, że głównym źródłem utrzymania

\footnotetext{
${ }^{5}$ Znany też w średniowieczu pod nazwą Ordo Sancti Salvatoris - tj. Zakon Najświętszego Zbawiciela.

${ }^{6} \mathrm{~W}$ tabeli 2 na stronie 183 znajduje się zestawienie pielgrzymek wymienionych w testamentach mieszczan Elblagga, Stralsundu i Lubeki.
} 
nowej fundacji będzie praca ręczna i zbieranie jałmużny (Biskup 1978a, s. 463). Zalecenia te w praktyce zupełnie się nie sprawdziły, bowiem brygidki prowadziły ekspansywną politykę w zakresie skupowania nieruchomości oraz samowolnego poszerzania ich granic poprzez anektowanie publicznych przestrzeni miejskich. Doszło nawet do tego, że kwestia konieczności zreformowania klasztoru brygidek w Gdańsku, obecności w nim dawnych pokutnic - prostytutek, a nawet możliwość kasaty tego klasztoru, były rozpatrywane na soborze w Konstancji w roku 1415 (Biskup 1978b, s. 614).

W 1391 roku święta Brygida została wyniesiona na ołtarze przez papieża Bonifacego IX, który w bulli kanonizacyjnej z niejakim zdziwieniem napisał: Ut etiam ab Aquilone aliquid boni esset, co w wolnym tłumaczeniu oznacza: „coś dobrego może również pochodzić z Północy”. Zdanie to dobitnie ilustruje, jak trudno byłoby prorokini z dalekiego kraju, dla współczesnych położonego na krańcach świata, przebić się do świadomości mieszkańców średniowiecznej Europy, gdyby nie jej 23 letni pobyt w Rzymie i niezwykła osobowość. Zresztą już kilka lat po kanonizacji, w roku 1396, ustanowiono ją patronką całej Szwecji, gdzie do chwili obecnej jest bardzo szanowana nie tylko jako święta, ale również jako wybitna Szwedka, która zapisała się na kartach światowej historii (Nordenfalk 1961, s. 372).

Już wkrótce po złożeniu jej ciała w klasztorze w Vadstenie zaczęli tu przybywać liczni pielgrzymi, którzy przywozili stąd charakterystyczne plakietki pielgrzymie z wizerunkiem świętej. W ikonografii jest ona na ogół przedstawiana jako zakonnica w habicie brygidek z welonem, na którym są umieszczone znamiona Męki Chrystusa, często siedząc przy pulpicie pisarskim, rzadziej stojąc w stroju pielgrzymim. Jej atrybuty to najczęściej anioł, korona, księga, kałamarz, kapelusz, sakwa i kij pielgrzymi, liście palmy, korona, krzyż, lew lub gorejące serce z krzyżem jerozolimskim. Anioł w tym przypadku zastępuje aureolę świętości, korona nawiązuje do nakrycia głowy brygidek, zdobionego krzyżem z białą hostią i pięcioma czerwonymi kropkami na wzór pięciu ran Chrystusa, księga i kałamarz to dowody na jej dokonania pisarskie, liście palmy świadczą o pielgrzymkach do Ziemi Świętej (gdzie powracających pielgrzymów nazywano palmieri), lew jest symbolem Szwecji, a serce oddaje znaczenie inicjatyw świętej Brygidy dla odmawiania nabożeństw do Serca Jezusa (Marecki, Rotter 2009, s. 131).

Liczne przepowiednie i proroctwa świętej Brygidy zostały wydane już w roku 1377, pod znaczącym tytułem Revelatione coelestes, tj. objawienia niebieskie, które w licznych odpisach krążyły po całej Europie. Oprócz tekstu zamieszczono tam również liczne ilustracje nawiązujące do wizji świętej oraz wizerunki jej samej w scenach nawiązujących do wybranych wątków tego dzieła (Nordenfalk 1961, s. 371-393).

Pierwsza drukowana wersja proroctw świętej Brygidy została wydana w Lubece w roku 1492 przez Bartholomeusa Gothana (Ryc. 2). W jednej ze swych 


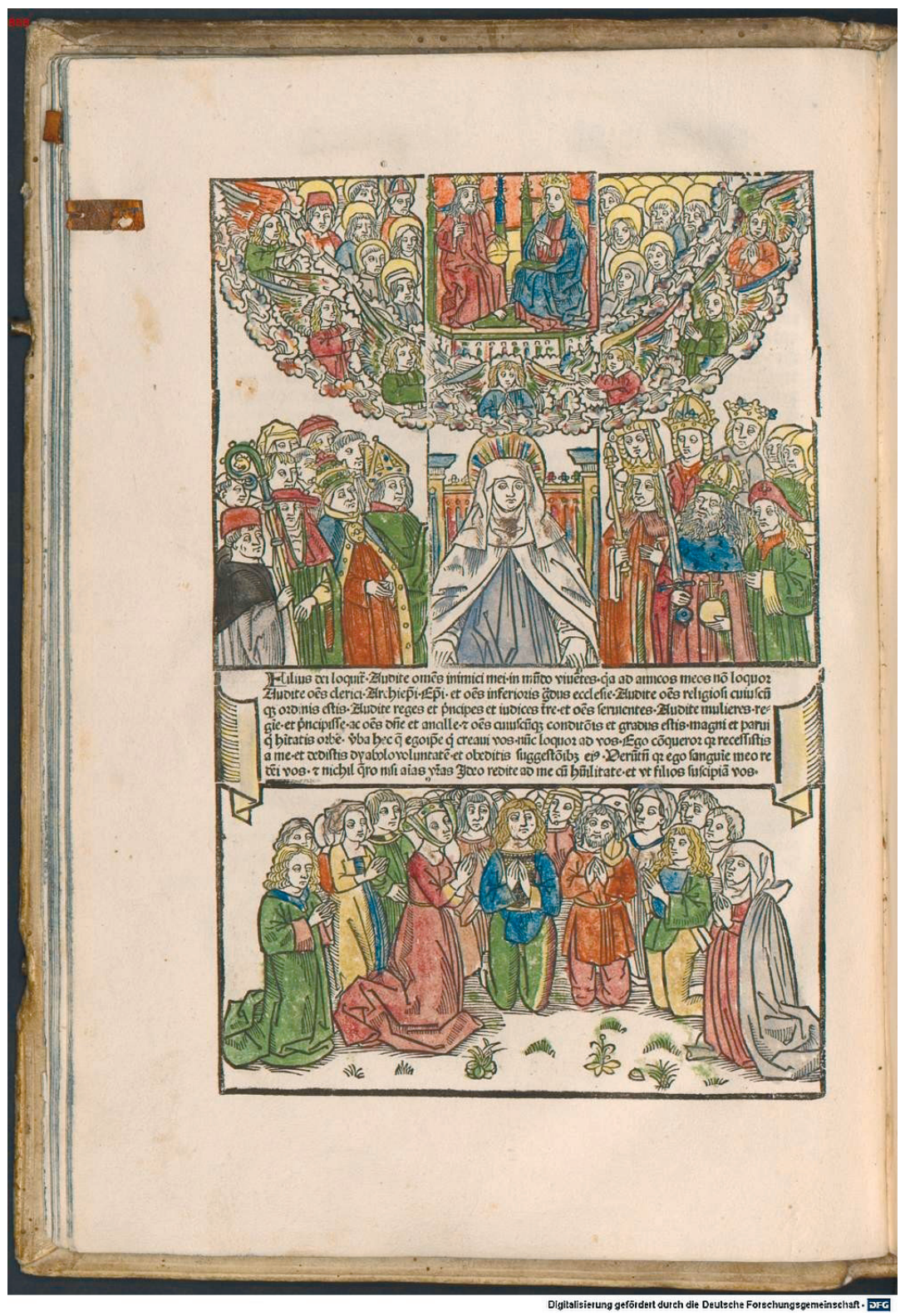

Ryc. 2. Wizerunek świętej Brygidy w jej dziele Revelationes caelestes wydrukowanym w Lubece w roku 1492 przez Barholomeusa Gothana (wg http://inkunabeln. digitale-sammlungen.deite_B-530,1,a12b.html, pobranie dn. 07.11.2016)

Fig. 2. The representation of St Bridget in her work Revelationes caelestes printed in Lübeck in 1492 by Barholomeus Gothan (after http://inkunabeln.digitale-sammlungen.deite_B-530,1,a12b.html, download on 07.11.2016) 
przepowiedni Brygida, poprzez usta nawiedzającej ją Marii Panny, przepowiedziała upadek państwa krzyżackiego7:

„Po tym Syn do mnie mówił, mówiąc: Pokazałem ci wyżej o pszczołach, że trojakie dobro mają od pszczelnika swego. Powiadam ci teraz że takie pszczoły mieli bydź oni krzyżacy, których na onych granicach Państw Chrześcijańskich posadziłem, ale już oni walczą przeciwko mnie, bo o duszę nie dbają. Nie mają też żalu nad onymi, którzy nawrócili się do wiary katolickiej y do mnie z błędu. Ściskają ich bowiem pracami, odejmują wolności, w wierze nie ćwiczą ich, od Sakramentów Świętych oddalają, y z większym żalem posyłają ich do piekła, niż gdy by w swojem nałożonym pogaństwie żyli, ani też walczą, tylko żeby rozszerzyli pychę swoje, y przyczynili chciwości swojej. Przeto przyjdzie im czas, kiedy będą połamane zęby ich, ręka prawa odcięta, a prawa noga oderwana będzie, aby żyli, y samych siebie poznali”.

Przepowiednia ta, jak wiele innych proroctw świętej Brygidy, sprawdziła się wiele lat po jej śmierci, za sprawą zwycięstwa polskiej armii nad wojskami krzyżackimi w bitwie pod Grunwaldem. Wdzięczny król Władysław Jagiełło ufundował w Lublinie w roku 1412 kościół, którego jedną z patronek była właśnie Święta Brygida Szwedzka.

Wracając do znaku pielgrzymiego z Vadsteny, znalezionego podczas badań wykopaliskowych przy ulicy Jaglanej na Wyspie Spichrzów w Gdańsku, warto zastanowić się nad kontekstem i lokalizacją tego odkrycia. W tej samej warstwie (nr 36 w wykopie IV) natrafiono także na inne średniowieczne pamiątki pielgrzymie. Jedna z nich to dolny fragment ażurowej plakietki, datowanej na XV wiek, z przedstawieniem postaci na tronie (GKPP 1112). Druga to kolista, gładka ramka datowana na 2. połowę XIV-początek XV wieku, z mniejszą ramką wewnątrz, zdobioną ornamentem perełkowym i osadzonymi na niej symetrycznie czterema koronami (GKPP 1114). Kolejne przedmioty to: miniaturowy grocik datowany na XV-XVI wiek (GKPP 1133), być może pochodzący z większej plakietki, plakietka pielgrzymia (zapewne z Osieków, gm. Sianów), datowana na XV wiek w formie kielicha z hostią i dwoma uchwytami po bokach, ze śladami po odłamanej głowie Chrystusa w górnej części (GKPP 1139), ażurowa grzechotka pielgrzymia także z XV wieku, z polami o trójkątnych kształtach (GKPP 1152), fragment plakietki w kształcie skrzydła, zapewne zdobiącego miniaturowy hełm, z XV-1. połowy XVI wieku, (GKPP 1153) oraz fragment ażurowej grzechotki pielgrzymiej z XV wieku, z zachowaną rękojeścią (GKPP 1166).

Absolutnym ewenementem jest również pochodzący z tej samej warstwy, doskonale zachowany gwizdek pielgrzymi z XV wieku, zdobiony plastycznymi

\footnotetext{
${ }^{7}$ Strona internetowa: www.objawienia.com; pobranie dn. 02.11.2016.
} 
skrzydełkami, z ruchomym wiatraczkiem umieszczonym tuż nad otworem akustycznym oraz znajdującym się pod spodem sztywnym kółkiem do zawieszania (GKPP 1168). Zbliżone do tego egzemplarza są dwa gwizdki pielgrzymie z Londynu, które posiadają podobne zakończenie (Spencer 1990, s. 63-64, 93, ryc. 195; 1998, s. 209, nr 216e) oraz gwizdek z Paryża, datowany na XV wiek, również z zachowanym wiatraczkiem, kręcącym się w trakcie dmuchania (Bruna 1996, s. 345-346, kat. 673).

Pozostałe pamiątki pielgrzymie zarejestrowane we wspomnianej warstwie to: toporek miniaturowy z XV wieku z plastycznym ornamentem czteroliścia na szyjce i strefowym ornamentem ukośnej kratki, biegnącym równolegle do ostrza (GKPP 1172), fragment ażurowej grzechotki pielgrzymiej z XV wieku (GKPP 1179), ażurowa plakietka datowana na czas od 1480 do 1. połowy XVI wieku, przedstawiająca postać rycerza z kopią (GKPP 1181) oraz miniaturowa muszelka z postacią świętego Jakuba z kijem pielgrzymim w prawej i księgą w lewej ręce, datowana na 2. połowę XV do początku XVI wieku (GKPP 1186).

Jak widać wszystkie te znaleziska chronologicznie mieszczą się w XV wieku, co może oznaczać, że warstwa nr 36 w wykopie IV jest świadectwem pobytu w tym stuleciu na Wyspie Spichrzów licznych pielgrzymów, którzy zanim zagubili tutaj swoje pamiątki, wcześniej nawiedzili europejskie sanktuaria. Z tych miejsc owe pamiątki przywieźli właśnie do Gdańska - ważnego dla nich przystanku bądź to w drodze powrotnej do domu, bądź też na trasie dalszych pielgrzymich peregrynacji. Z przedstawionego wyżej kontekstu dowodnie mamy tu pamiątki z Vadsteny, zapewne Osieków na Pomorzu oraz Santiago de Compostela, a także z kilku nieustalonych europejskich sanktuariów, zatem mamy pośredni dowód na to, że właśnie na Wyspie Spichrzów w Gdańsku krzyżowały się drogi pielgrzymów z wielu krajów europejskich. Potwierdza to zdecydowanie zbiór wszystkich pamiątek pielgrzymich znalezionych w trakcie badań wykopaliskowych prowadzonych przy ulicy Jaglanej 3/5 - blisko 100 przedmiotów o charakterze zarówno sacrum jak i profanum. Pośród tych pierwszych rozpoznano jak dotąd plakietki z Ninove, Wilsnack, Sternbergu, Kolonii, Osieków(?), zapewne Düren, Güstrow, Wesel(?), Akwizgranu, Königslutter, Trewiru, Maastricht, Santiago de Compostela oraz Góry Chełmskiej koło Koszalina i Jakobsbergu. Ośrodków, z których mogli podróżować pielgrzymi, może być jednak znacznie więcej, jako że w odniesieniu do kilkudziesięciu przedmiotów nadal nie jest znane miejsce ich pochodzenia.

Początki planowego zagospodarowania Wyspy Spichrzów w świetle badań archeologicznych datowane są na 1. połowę XIV wieku i wiążą się z ekspansją Głównego Miasta na wschód oraz rozbudową portu gdańskiego. Rejon ulicy Jaglanej (Hirsegasse), dawniej Czajczej (Kiebitzgasse), wymienianej w 2. połowie XIV wieku jako twergasse, położony jest w południowej części wyspy, gdzie w późnym średniowieczu dominowały składy drewna przeznaczonego na eksport - tzw. pola drzewne. Na północ od ulicy Jaglanej pojawiała się też ulica Wspornikowa 
(Stützengasse), wówczas jeszcze określona jedynie jako via, za którą, w środkowej części wyspy, aż do obecnej ulicy Zarzewie, rozciągał się zagajnik (nemus). W księdze spadkowej z 1385 roku czytamy o naturalnym rozgraniczeniu wyspy przez zarośla i pastwiska, przy czym na północny wschód od nich znajdowały się wówczas spichlerze, a na południowy zachód place drzewne (Holsteden). Pola te, opisane jako pola drzewne aż do mostu (holsteden up dem brucke), rozciągały się od obecnej ulicy Wspornikowej do ulicy Toruńskiej. W XV wieku place drzewne sukcesywnie ustępowały miejsca nowo budowanym spichlerzom, szczególnie nad brzegami Motławy. Niemniej jeszcze około roku 1490 nadal istniał duży plac drzewny w południowo-zachodniej części wyspy, usytuowany naprzeciw Targu Stępki (Kielmarkt). Około roku 1500 własny plac drzewny oraz spichlerz posiadał przy ul. Czajczej kościół Mariacki, a kościół św. Jana był właścicielem spichlerza przy ulicy Wspornikowej (Volkholz 1922, s. 28-32). W latach 1516-1517 wschodni kraniec wyspy, poprzednio broniony palisadą, został ufortyfikowany wałem ziemnym (tzw. Psi Wał). Od początku XVI wieku dawne place drzewne ulegały sukcesywnej zabudowie spichlerzami, co poświadczone jest w księgach czynszowych gruntów z lat 1500 i 1530, a łączna liczba spichrzów odnotowanych na wyspie 100 lat później przekroczyła 300 obiektów.

Wyspa Spichrzów w XV wieku, podobnie jak tereny Lastadii leżącej po przeciwnej stronie Starej Motławy, gdzie budowano i reperowano statki, nie były zajęte przez zabudowę mieszkalną. Nazwa Lastadia (Łasztownia) występuje w źródłach już w 1361 roku, w kontekście funkcjonowania w tym miejscu wspomnianych warsztatów okrętowych oraz - położonych przy zachodnim skraju terenów stoczniowych - zabudowań mieszkalnych dla pracujących tam rzemieślników. Obok warsztatów szkutniczych na Lastadii funkcjonował także port pasażerski, z którego niewątpliwie korzystali także pielgrzymi, o czym mogą świadczyć liczne plakietki pielgrzymie znalezione na tym obszarze. Spośród ponad 120 takich przedmiotów rozpoznano plakietki z Akwizgranu, Amersfoort, Einsiedeln, Góry Chełmskiej, Neuss, Königslutter, Blombergu, Sternbergu, Thann, Le Mont-Saint-Michel, Osieków, Wilsnack, Nikolausberg, Maastricht, Bremy, Kolonii, Santiago de Compostela oraz Wesel; dla kilkudziesięciu znaków nie zidentyfikowano miejsca pochodzenia. Jak widać, w kilku przypadkach plakietki pochodziły z tych samych sanktuariów, co egzemplarze znalezione po drugiej stronie Starej Motławy, niemniej w obrębie tego samego portu.

To, że pielgrzymi licznie korzystali z transportu morskiego nie ulega najmniejszej wątpliwości. O ile jednak z pielgrzymek do Ziemi Świętej dysponujemy licznymi źródłami i opracowaniami na ten temat (Quirini-Popławska 1995, s. 126-143), o tyle odnośnie przewozów pielgrzymów na wodach Morza Bałtyckiego i Morza Północnego wciąż wiadomo stosunkowo niewiele, choć w publikacjach z ostatnich lat również na ten temat znajdujemy kilka interesujących informacji. Wiadomo, że w XV wieku podróż z Gdańska do Lubeki trwała średnio od czterech do pięciu dni, 
z kolei z Lubeki do Bergen od dziewięciu dni nawet do trzech tygodni. W opinii Henryka Samsonowicza podróż morska z Gdańska do Santiago de Compostela trwała wówczas 15 dni, a podróż lądowa około 70 dni (Samsonowicz 2002, s. 128). Statki przewożące pielgrzymów do Santiago de Compostela cumowały w portach La Coruna i El Padron (Taracha 1993, s. 78). Marian Rębkowski również zakładał możliwość odbywania znacznej części pielgrzymek drogą morską (Rębkowski 2002, s. 265-269). Niewątpliwie taki sposób podróżowania nie tylko umożliwiał dotarcie do zamorskich, odległych sanktuariów, ale też znacząco skracał czas peregrynacji, co dla wielu pielgrzymów miało ogromne znaczenie. Nie zawsze jednak był on bezpieczny, nie tylko ze względu na pirackie napady, ale też złe warunki pogodowe. W roku 1372, statek transportujący liczną grupę pielgrzymów natrafił na sztorm; wielu z nich utonęło co odnotowano w kronikach: „,...] przez wiatr i wielką burzę zaskoczeni, wiele osób utonęło, dobrze 90 osób, młodych i starych, kobiety, dzieci, biedaków i służących, dwóch rodzajów bogatych i biednych" (Łysiak 2003, s. 49).

Pielgrzym, który zgubił plakietkę z Vadsteny szczęśliwie odbył podróż morska, choć - być może - wcale jeszcze nie zakończył pobożnych peregrynacji, podobnie jak pielgrzymi powracający z wielu innych sanktuariów, którzy właśnie w Gdańsku pozostawili materialne świadectwa swych wędrówek.

\section{Literatura}

Andersson L.

1985 Pilgrimsmärke och vallfahrtsbild. Två svenska exempel från 1400-talet, Konsthistoriska studier 8, Sztokholm.

1986 Sankta Brigittas pilgrimsmärken, [w:] Medeliten och arkeologin. Festskrift till Erik Cinthio, red. A. Andrén, Lund Studies in Medieval Archaeology 1, Lund, s. 101-115.

1989 Pilgrimsmärken och vallfart. Medeltida pilgrimskultur i Skandinavien, Lund Studies in Medieval Archaeology 7, Lund.

Ansorge J.

2013 Pilgerzeichen und Pilgerforschung in Mecklemburg-Vorpommern, [w:] Europäische Wallfahrtsstudien, t. 10: Wallfahrer aus dem Osten Mittelalterliche Pilgerzeichen zwischen Ostsee, Donau und Seine. Beiträge der Tagung Perspektiven der europäischen Pilgerzeichenforschung 21. bis 24. April 2010 in Prag, red. H. Kühne, L. Lambacher, J. Hrdina, Frankfurt am Main, s. 81-143. Ansorge J., Kühne H.

2009 Barfu $\beta$ und in Wolle gekleidet... Pilger in Güstrow, Archäologie in Deutschland 2009(2), s. 46-47. 
Biskup M.

1978a Pod panowaniem krzyżackim - od 1308 r. do 1454 r. Gdańsk w pierwszym stuleciu rzadów krzyżackich (1308-1409). Kultura, [w:] Historia Gdańska, t. 1: Do roku 1454, red. E. Cieślak, Gdańsk, s. 446-474.

1978b Pod panowaniem krzyżackim - od 1308 r. do 1454 r. Gdańsk u schyłku rząów krzyżackich (1409-1454). Kultura, [w:] Historia Gdańska, t. 1: Do roku 1454, red. E. Cieślak, Gdańsk, s. 605-624.

Bruna D.

1996 Enseignes de Pèlerinage et Enseignes Profanes, Paris.

2006 Enseignes de plomb et autres menues chosettes de Moyen Âge, Paris.

Catalogue

1954 Catalogue of the Museum of London Antiquities Collected by, and the property of Charles Roach Smith, London.

Czaja K.

1998 Bazylika Mniejsza Św. Brygidy Historia i współczesność, Warszawa. Fankidejski J.

2011 Obrazy cudowne i miejsca $w$ dzisiejszej diecezji chetmińskiej podług urzędowych akt kościelnych i miejscowych podań, reprint wydania z Pelplina z 1880 roku, wyd. 1, Gdynia.

Gerhardt J., Neu H., Renard E., Verbeek A., mit einem beitrag von r. V. Uslar

1938 Die Kunstdenkmäler des Kreises Ahrweiler, Die Kunstdenkmäler der Rheinprovinz, t. 17.1, Düsseldorf.

Hauglid R.

1942 Pilegrimsmerker på kirkeklokker, Foreningen til Norske Fortidsminnesmerkers Bevaring. Årsberetning 1942, s. 61-72.

Kamińska S.

1970 Klasztory brygidek w Gdańsku, Elblagu i Lublinie. Założenie i uposażenie, Gdańsk.

Keyser E.

1928 Danzigs Geschichte, Danzig.

Köster K.

1979 Alphabet-Inschriften auf Glocken. Mit einem europäischer ABC-Glocken vom 12. bis zum 18. Jahrhundert, [w:] Studien zur deutschen Literatur des Mittelalters, red. R. Schützeichel, Bonn, s. 371-422.

1983 Pilgerzeichen und Pilgermuscheln von mittelalterlichen Santiago-Straßen: Saint-Léonard - Rocamadour - Saint-Gilles - Santiago de Compostela, Ausgrabungen in Schleswig, Berichte und Studien 2, Neumünster.

Kubicki R.

2010 Pielgrzymki w testamentach mieszczan elblqskich $w$ XV-poczatkach XVI w., [w:] Z dziejów średniowiecza. Pamięci profesora Jana Powierskiego (1940-1999), red. W. Długokęcki, Gdańsk, s. 179-188.

2011 Formy pobożności w mieście późnośredniowiecznym w świetle zapisów na rzecz kościoła i biednych $w$ testamentach elblaskich (XV-poczatek XVI wieku), Zapiski historyczne, t. 76, z. 2, s. 7-26. 
Łysiak W.

2003 Z pielgrzymim kijem przez średniowieczne Pomorze, [w:] Życie dawnych Pomorzan, t. 2, red. W. Łysiak, Bytów-Słupsk, s. 45-52.

Majewski M.

2013 Pilgerzeichen auf Glocken in hinterpommerschen Kirchen, [w:] Europäische Wallfahrtsstudien, t. 10: Wallfahrer aus dem Osten Mittelalterliche Pilgerzeichen zwischen Ostsee, Donau und Seine. Beiträge der Tagung Perspektiven der europäischen Pilgerzeichenforschung 21. bis 24. April 2010 in Prag, red. H. Kühne, L. Lambacher, J. Hrdina, Frankfurt am Main, s. 51-68.

Marecki J., Rotter L.

2009 Jak czytać wizerunki świętych, Leksykon atrybutów i symboli hagiograficznych, Kraków.

Mitchiner M.

1986 Medieval Pilgrims Souvenirs and Secular Badges, London.

Nordenfalk C.

1961 Saint Bridget of Sweden as represented in illuminated manuscripts, [w:] De Artibus Opuscula XL: Essays in Honor of Erwin Panofsky, red. M. Meiss, New York, s. 371-393.

Paner $\mathrm{H}$.

2013 Średniowieczne świadectwa Kultu Maryjnego. Pamiatki pielgrzymie w zbiorach Muzeum Archeologicznego w Gdańsku, Seria Fontes Commentationesque ad Res Gestas Gedani et Pomeraniae, t. 4, Gdańsk.

Poettgen J.

2009 Karl der Große auf Aachener Pilgerzeichen des Mittelalters. Mit einem Katalog der bisher bekannten Exemplare, Zeitschrift des Aachener Geschichtsvereins, t. 110, s. 65-100.

Quirini-Popławska D.

1995 Wenecja jako etap podróży do Ziemi Świętej (XIII-XV w.), [w:] Peregrinationes. Pielgrzymki w kulturze dawnej Europy, Colloquia Mediaevalia Varsoviensia II, red. H. Manikowska, H. Zaremska, Warszawa, s. 126-143.

Rębkowski M.

2002 ...ad sanctum Jacobum ultra montes... Przyczynek do badań nad pielgrzymkami mieszczan kołobrzeskich w średniowieczu, [w:] Civitas et villa. Miasto i wieś w średniowiecznej Europie Środkowej, red. C. Buśko i in., WrocławPraha, s. 265-269.

Rhein und maas

1972 Rhein und Maas. Kunst und Kultur 800-1400. Eine Ausstellung des Schnütgen-Museums der Stadt Köln und der belgischen Ministerien für französische und niederländische Kultur, red. A. Legner, Köln.

Rong P.

2000 Mittelalterliche Aachener Pilgerzeichen aus der Zeit des 14. bis 16. Jahrhunderts, Aachen. 
Rydbeck M.

1957

Ett pilgrimsmärke från Alvastra och Gutenbergs „Aachener Heiltumsspiegel”, Fornvännen 52, s. 294-304.

Samsonowicz H.

2002 Kult św. Jakuba i szlaki jakubowe w Polsce, [w:] Kult św. Jakuba Większego apostoła w Europie Środkowo-Wschodniej, red. R. Knapiński, Lublin, s. $125-129$.

Spencer B.

1990 Pilgrim Souvenirs and Secular Badges, Salisbury and South Wiltshire Museum Medieval Catalogue Part 2, Salisbury.

1998 Pilgrim Souvenirs and Secular Badges, Medieval Finds from Excavations in London 7, London.

Taracha C.

1993 Szlaki pielgrzymkowe do Composteli w średniowiecznej Hiszpanii, [w:]

Pielgrzymki w kulturze średniowiecznej Europy. Materiały z XIII Seminarium

Mediewistycznego, red. J. Wiesiołowski, Poznań, s. 77-83.

Ugglas af C. F.

1943 Den 'extatiska' Birgitta i Vadstenie klosterkyrka, Fornvännen, Journal of Swedish Antiquarian Research, Stockholm, s. 65-90.

Uldall F.

1906 Danmarks middelalderlige Kirkeklokker, Köpenhamn.

Volkholz F.

1922 Die Spicherinsel von Danzig, Danzig.

Wallem F. B.

1930 Middelalderske kirkeklokker i Norge med. St Olavs billede eller navn, Det Konglige Norske Videnskabers Selskabs, Forhandlinger 3(8), Trondheim, s. 32-35.

\section{THE PILGRIM SIGN OF THE SAINT BRIGIT FROM GDANSK AND OTHER ARCHAEOLOGICAL TESTIMONY OF THE SAINT BRIGIT CULT IN THE EUROPEAN DISCOVERIES}

Summary

During the excavations conducted in Gdansk in 2012 near Jaglana Street, in the layer 36, dated to the late medieval period, was discovered perfectly preserved medieval pilgrims sign showing the figure of Saint Brigit sitting next to the writer desktop. Above, in the clearly marked sphere of the heaven, there are heads of Mary and Christ. In the bottom of the badge frame is poorly preserved inscription S'BIRGITTA DE WATZSTEIS. This sign came from monastery in Vadstenie in Sweden located in Östergötland - the headquarters of the Bridgettines Order, founded by St. Bridget in 1346. Location previously known other European discoveries may indicate that this shrine was visited mainly by the inhabitants of Scandinavia, as badges of Vadstenie are known so far in the number more than sixty, only from the discoveries made in Sweden, Norway, Denmark and Finland. The finding of Gdansk is the first discovery of the original Vadstenie badge in 
this part of Europe, and according to the author, as well as other finds pilgrim souvenirs from the area of the medieval Gdansk's port, there is a testimony of the importance the city of Gdansk on pilgrimage routes of medieval Europe.

Translated by Henryk Paner 